\title{
Blood Glucose and Renal Function Evaluation in Patients with Viral Hepatitis
}

\author{
Wen-Tung Hsu' \\ Deng-Ho Yang ${ }^{1-4}$ \\ Chun-Cheng Liao $\mathbb{1 D}^{3,5}$ \\ Jia -Wen Chen ${ }^{6}$ \\ Wen-Hsiu $\mathrm{Hsu}^{3,7}$ \\ Chia-Wen Kuo ${ }^{3,8}$ \\ Hung-Chang Hsu (iD ${ }^{9}$ \\ Sheng-Huang Chang ${ }^{10}$ \\ Li-Mien Chen ${ }^{2,3}$ \\ 'Division of Laboratory, Taichung Armed \\ Force General Hospital, Taichung, Taiwan, \\ Republic of China; ${ }^{2}$ Department of Internal \\ Medicine, Taichung Armed Force General \\ Hospital, Taichung, Taiwan, Republic of \\ China; ${ }^{3}$ School of Medicine, National \\ Defense Medical Center, Taipei, Taiwan, \\ Republic of China; ${ }^{4}$ Department of Medical \\ Laboratory Science and Biotechnology, \\ Central Taiwan University of Science and \\ Technology, Taichung, Taiwan, Republic of \\ China; ${ }^{5}$ Department of Family Medicine, \\ Taichung Armed Force General Hospital, \\ Taichung, Taiwan, Republic of China; \\ ${ }^{6}$ Medicine Laboratory, Ministry of Health \\ and Welfare Feng Yuan Hospital, Taichung, \\ Taiwan, Republic of China; ${ }^{7}$ Division of \\ Gastroenterology, Taichung Armed Force \\ General Hospital, Taichung, Taiwan, \\ Republic of China; ${ }^{8}$ Division of Nephrology, \\ Taichung Armed Force General Hospital, \\ Taichung, Taiwan, Republic of China; \\ ${ }^{9}$ Division of Laboratory, Ching Chyuan \\ Hospital, Taichung, Taiwan, Republic of \\ China; ${ }^{10}$ Tsaotun Psychiatric Center, \\ Ministry of Health and Welfare, Nantou, \\ Taiwan, Republic of China
}

Correspondence: Li-Mien Chen Department of Internal Medicine, Taichung Armed Force General Hospital, No. 348, Sec. 2, Chung-Shan Road, Taiping, Taichung, Taiwan, Republic of China

Email c332860@ms65.hinet.net
Purpose: To evaluate the blood glucose and renal function, determine the prevalence of hyperglycemia/diabetes mellitus (DM) and renal disease (nephropathy), and investigate the association between hyperglycemia/DM and renal disease in patients with viral hepatitis (VH).

Patients and Methods: A total of 491 subjects were included in the study. Patients with $\mathrm{VH}$ were further divided into the hepatitis $\mathrm{B}$ virus (HBV) infection, hepatitis $\mathrm{C}$ virus (HCV) infection, and HBV-HCV co-infection subgroups. Fasting blood glucose, glycated hemoglobin (HbA1c), glycated albumin (GA), glutamic oxaloacetic transaminase (GOT), creatinine (Cr), and cystatin C (Cys C) levels were measured. Urine microalbumin levels were also assessed. Formulas for estimated average glucose calculated using glycated albumin (eAG(GA)), estimated average glucose calculated using HbA1c (eAG(HbA1c)), and estimated glomerular filtration rate calculated using cystatin $\mathrm{C}$ (eGFRcys) were used to evaluate the average glucose and renal function.

Results: The prevalence of hyperglycemia/DM and renal disease was significantly higher in the VH group, especially in the HCV subgroup. The prevalence of renal disease was significantly higher in patients with $\mathrm{VH}$ with $\mathrm{eAG}(\mathrm{GA}) \geq 200 \mathrm{mg} / \mathrm{dL}$.

Conclusion: Our study used multiple parameters to evaluate blood glucose and renal function in patients with $\mathrm{VH}$ and found that hyperglycemia/DM and renal disease are closely associated with VH, especially in subjects with HCV infection. Patients with VH, especially those with $\mathrm{HCV}$ infection and hyperglycemia/DM, were particularly vulnerable to renal disease.

Keywords: viral hepatitis, hyperglycemia, diabetes mellitus, renal disease, nephropathy

\section{Introduction}

Viral hepatitis (VH) is one of the most serious public health issues worldwide. Millions of people are infected each year, and 1.4 million people die from $\mathrm{VH}-$ related complications (such as cirrhosis and liver cancer). According to the World Health Organization (WHO), hepatitis B (HBV) and hepatitis C (HCV) viruses are the main causes of $\mathrm{VH}$ infection. ${ }^{1}$ It is estimated that 325 million people worldwide have hepatitis B and/or hepatitis C. Among those with VHrelated complications, hepatitis $\mathrm{B}$ and/or $\mathrm{C}$ accounted for $96 \%$ of the mortality. ${ }^{2}$

VH infection often has extrahepatic manifestations (XMs), such as hyperglyce$\mathrm{mia} / \mathrm{DM}$ and renal disease. ${ }^{3}$ In a meta-analysis by Younossi et al the prevalence of diabetes was reported to be $15 \%$ in Western countries; ${ }^{4}$ additionally, in a systematic review with meta-analysis they reported that the pooled prevalence of type 2 diabetes mellitus (T2DM) and chronic kidney disease (CKD) was 19.0\% and 9.2\%, respectively, in East Asian patients with $\mathrm{HCV}^{3,5}$ 
The aim of this study was to evaluate the blood glucose level and renal function, determine the prevalence of hyperglycemia/DM and renal disease (nephropathy), and investigate the association between hyperglycemia/DM and renal disease in patients with $\mathrm{VH}$.

\section{Patients and Methods}

\section{Ethics Statement and Research Data Collection}

After obtaining approval from the Human Body Trials/ Research Program of the Tri-Service General Hospital (Research IRB review number: TC102-01), volunteers who signed the informed consent were randomly recruited from the Department of Metabolism, Gastroenterology, and Nephrology. A preliminary screening was conducted to identify subjects as healthy controls and patients with VH and classify the disease groups according to the participant's health status, clinical examination results (medical history and physical examination), physiological data, etc.

\section{Testing Method}

Specimen collection: Blood samples were collected, after a 10-h overnight fast, in a test tube without any anticoagulant. The samples were allowed to stand at room temperature for 30 minutes and coagulate completely; they were then centrifuged at $1800 \mathrm{~g}$ for $10 \mathrm{~min}$. The serum was immediately separated for creatinine $(\mathrm{Cr})$, glucose, glycated hemoglobin (HbA1c), glycated albumin (GA), glutamic oxaloacetic transaminase (GOT), $\beta_{2}$ microglobulin, and cystatin $\mathrm{C}$ (Cys C) assays. Fresh mid-section urine samples were collected and centrifuged at $1800 \mathrm{~g}$ for $5 \mathrm{~min}$ for the microalbumin assay.

Test grouping: The study participants were divided into the control and $\mathrm{VH}$ groups. Patients in the $\mathrm{VH}$ group were divided into hepatitis B virus (HBV), hepatitis $\mathrm{C}$ virus (HCV), and hepatitis $\mathrm{B}+\mathrm{C}$ (HBV-HCV) coinfected subgroups. Based on the estimated average glucose level calculated using glycated albumin(eAG (GA)), the HBV, HCV, and HBV-HCV subgroups were further divided into eAG(GA) $\geq 200 \mathrm{mg} / \mathrm{dL}$ and eAG(GA) $<200 \mathrm{mg} / \mathrm{dL}$ groups. Nephropathy was defined as the third stage of CKD and an estimated glomerular filtration rate (eGFR) $<60 \mathrm{~mL} / \mathrm{min}$ in our study. ${ }^{6,7}$ Descriptive statistical analysis was performed to compare the differences between the groups.

Testing equipment: For the urine/biochemical tests, the "Beckman Coulter" Automated Chemistry Analyzer
AU680 (Beckman Coulter Mishima K.K. Shizuoka, Japan) was used; for HbAlc tests, the "TOSOH" Automated G7 HPLC Glycohemoglobin Analyzer (International Diagnostic Equipment [IDE], Temecula, CA, USA) was used.

Test reagents: The following were the test reagents used: $\mathrm{Cr}$, glucose, GOT, $\beta_{2}$ microglobulin, urine microalbumin ([MA], Olympus Diagnostic GmbH, Lismeehan, O'Callaghan's Mills, Co. Clare, Ireland), HbA1c (Tosoh Bioscience GmbH, Griesheim, Germany), glycated albumin (Lucica GA-L) (Asahi Kasei Pharma Corporation, Tokyo, Japan), cysteine acid protein C, and "Siemens" N Latex Cystatin C (Siemens Healthcare Diagnostics Product GmbH, Marburg, Germany).

\section{Formulas}

1. Estimated average glucose calculated using glycated albumin: eAG(GA) $(\mathrm{mg} / \mathrm{dL})=$ $4.71 \mathrm{GA} \%+73.35^{8}$

2. Estimated average glucose calculated using $\mathrm{HbAlc}$ : $\mathrm{eAG}(\mathrm{HbAlc})(\mathrm{mg} / \mathrm{dL})=28.7 \times \mathrm{HbAl}(\%)$ $-46.7^{9,10}$

3. Estimated glomerular filtration rate calculated using cystatin C (eGFRcys): eGFRcys $\left(\mathrm{mL} / \mathrm{min} / 1.73 \mathrm{~m}^{2}\right)$ $=76.7 \times$ sCystatin $\mathrm{C}^{-1.1911}$

\section{Statistical Methods}

The narrative statistical results were compared between the groups. The variables were expressed as the mean and standard deviation of concentration and dispersion to describe the characteristics of the participants. Differences between the demographic variables with respect to the dependent variable were assessed for significance using the chi-square test as appropriate. Statistical software SPSS (version 18; SPSS, Chicago, IL, USA) was used analyses. For continuous variables and normally distributed variables, Student's $t$-test or analysis of variance was used to confirm the degree of difference between the groups. Univariate and multivariate logistic regression models (Enter method) were performed to investigate the association between hyperglycemia and nephropathy in both viral hepatitis and non-viral hepatitis subgroups where demographic variables were included as confounders. The logistic regression models were analyzed to determine the possible risk factors for nephropathy, and the significance was set at $\mathrm{p}<0.05$. 


\section{Results}

\section{Basic Data}

This study included 491 participants (221 males and 270 females). Of these, 244 healthy participants were assigned to the control group and 247 patients with $\mathrm{VH}$ were assigned to the VH group. (Tables 1 and 2)

\section{Glucose, eAG(GA), and eAG(HbAlc)}

The average levels of glucose, eAG(GA), and eAG (HbA1c) were significantly higher in the $\mathrm{VH}$ group than in the control group, with a significant difference between the HCV subgroup and control group. (Tables 1 and 2; Figure 1A)

\section{HbAlc}

The prevalence of HbAlc level $>6.5 \%$ in the $\mathrm{VH}$ group was $21.5 \%$ and 0 in the control group. The prevalence rates of $\mathrm{HbA} 1 \mathrm{c}>6.5 \%$ in the $\mathrm{HBV}, \mathrm{HCV}$, and $\mathrm{HBV}-\mathrm{HCV}$ subgroups were $20.0 \%, 29.3 \%$, and $15.9 \%$, respectively.

\section{Cr, Cys $C, \beta_{2}$-Microglobulin, and Urine Microalbumin} The average levels of $\mathrm{Cr}$, $\mathrm{Cys} C$, and $\beta_{2}$-microglobulin were higher in the $\mathrm{VH}$ group than in the control group, with a significant difference between the HCV subgroup and control group. The average level of urine microalbumin was higher in the $\mathrm{VH}$ group than in the control group. (Tables 1 and 2; Figure 1B)

Table I Basic Data of the Control and VH Groups ( $t$ Test)

\begin{tabular}{|c|c|c|c|c|}
\hline Group & All $(N=49 I)$ & Control (T) $(n=244)$ & Viral Hepatitis $(V)(n=247)$ & $\mathbf{P}$ \\
\hline Male & 221 & 85 & 136 & \\
\hline Female & 270 & 159 & I I I & \\
\hline Age, year & $50.7 \pm 11.5$ & $50.4 \pm 7.6$ & $50.9 \pm 14.4$ & \\
\hline GOT, U/L & $27.4 \pm 27.9$ & $18.3 \pm 4.4$ & $34.6 \pm 35.6 * * *$ & $<0.001 * * *$ \\
\hline Glucose, mg/dL & $101.2 \pm 29.0$ & $94.1 \pm 8.4$ & $108.2 \pm 38.8^{* * *}$ & $<0.001 * * *$ \\
\hline eAG(GA), mg/dL & $202.8 \pm 52.3$ & $169.3 \pm 16.1$ & $208.2 \pm 54.1^{* * *}$ & $<0.00 I^{* * *}$ \\
\hline eAG(HbAlc), mg/dL & $128.5 \pm 35.4$ & $111.9 \pm 7.0$ & $|3| .6 \pm 37.6 * * *$ & $<0.00 I^{* * *}$ \\
\hline $\mathrm{Cr}, \mathrm{mg} / \mathrm{dL}$ & $0.82 \pm 0.29$ & $0.75 \pm 0.17$ & $0.89 \pm 0.37^{* * *}$ & $<0.001 * * *$ \\
\hline Cys C, mg/L & $0.90 \pm 0.30$ & $0.79 \pm 0.14$ & $0.92 \pm 0.32 *$ & $=0.019 *$ \\
\hline$\beta_{2}-\mathrm{MG}, \mathrm{ug} / \mathrm{dL}$ & $2.12 \pm 1.07$ & $1.70 \pm 0.50$ & $2.19 \pm 1.12^{* *}$ & $=0.006 * *$ \\
\hline MA, mg/dL (mini, max) & $22.3 \pm 105.2(0,864)$ & $9.9 \pm 29.9(0,127)$ & $24.7 \pm 114.2(0,864)$ & \\
\hline
\end{tabular}

Notes: $* \mathrm{P}<0.05$, $* * \mathrm{P}<0.01$, $* * * \mathrm{P}<0.00$ I; compare each with the control group.

Abbreviations: GOT, glutamic oxaloacetic transaminase; eAG(GA), estimated average glucose of glycated albumin; eAG(HbAlc); HbAlc-derived average glucose; Cr, serum creatinine; Cys $C$, cystatin $C ; \beta_{2}-M G, \beta_{2}$-microglobulin; MA, microalbumin; eGFRcys, estimated glomerular filtration rate level with calculated by Cys $C$.

Table 2 Basic Data of the Three Subgroups of HBV, HCV, and HBV-HCV (ANOVA)

\begin{tabular}{|c|c|c|c|c|c|c|}
\hline Group & $\begin{array}{l}\text { Control }(T) \\
(n=244)\end{array}$ & HBV (B) $(n=145)$ & $\operatorname{HCV}(C)(n=58)$ & $\begin{array}{c}\text { HBV-HCV (O) } \\
(n=44)\end{array}$ & $\mathbf{p}$ & $\begin{array}{c}\text { Scheffe Post } \\
\text { Hot }\end{array}$ \\
\hline Male & 85 & 84 & 22 & 30 & & \\
\hline Female & 159 & 61 & 36 & 14 & & \\
\hline Age, year & $50.4 \pm 7.6$ & $49.7 \pm 15.2$ & $53.9 \pm 11.7$ & $50.7 \pm 14.7$ & 0.120 & \\
\hline GOT, U/L & $18.3 \pm 4.4$ & $31.1 \pm 35.0$ & $34.7 \pm 31.6$ & $46.0 \pm 27.9$ & $<0.001$ & $\begin{array}{c}\mathrm{T}<\mathrm{B}, \mathrm{C}, \mathrm{O} ; \mathrm{B}<\mathrm{O} ; \\
\mathrm{C}<\mathrm{O}\end{array}$ \\
\hline Glucose, mg/dL & $94.1 \pm 8.4$ & $105.9 \pm 34.7$ & $112.4 \pm 37.0$ & $110.4 \pm 52.3$ & $<0.001$ & $\mathrm{~T}<\mathrm{B}, \mathrm{C}, \mathrm{O}$ \\
\hline eAG(GA), mg/dL & $169.3 \pm 16.1$ & $204.7 \pm 52.0$ & $223.6 \pm 65.2$ & $201.0 \pm 42.3$ & $<0.001$ & $\mathrm{~T}<\mathrm{B}, \mathrm{C}$ \\
\hline $\mathrm{e} A \mathrm{G}(\mathrm{HbA} \mid \mathrm{c}), \mathrm{mg} / \mathrm{dL}$ & $111.9 \pm 7.0$ & $129.9 \pm 36.3$ & $137.7 \pm 42.9$ & $129.0 \pm 34.1$ & $<0.001$ & $\mathrm{~T}<\mathrm{B}, \mathrm{C}$ \\
\hline $\mathrm{Cr}, \mathrm{mg} / \mathrm{dL}$ & $0.75 \pm 0.17$ & $0.87 \pm 0.30$ & $0.93 \pm 0.52$ & $0.89 \pm 0.32$ & $<0.001$ & $\mathrm{~T}<\mathrm{B}, \mathrm{C}, \mathrm{O}$ \\
\hline Cys C, mg/L & $0.79 \pm 0.14$ & $0.89 \pm 0.25$ & $1.05 \pm 0.50$ & $0.89 \pm 0.20$ & $<0.001$ & $\mathrm{~T}<\mathrm{C} ; \mathrm{B}<\mathrm{C}$ \\
\hline$\beta_{2}-\mathrm{MG}, \mathrm{ug} / \mathrm{dL}$ & $1.70 \pm 0.50$ & $2.05 \pm 0.94$ & $2.65 \pm 1.55$ & $2.07 \pm 0.83$ & $<0.001$ & $\mathrm{~T}<\mathrm{C} ; \mathrm{B}<\mathrm{C}$ \\
\hline $\begin{array}{l}\text { MA, mg/dL (mini, } \\
\max )\end{array}$ & $9.9 \pm 29.9(0,127)$ & $25.8 \pm I 20 . I(0,864)$ & $16.3 \pm 59.6(0,430)$ & $32.4 \pm 63.5(0,795)$ & 0.659 & \\
\hline
\end{tabular}

Abbreviations: GOT, glutamic oxaloacetic transaminase; eAG(GA), estimated average glucose of glycated albumin; eAG(HbAlc); HbAlc-derived average glucose; Cr, serum creatinine; Cys $C$, cystatin $C ; \beta_{2}-M G, \beta_{2}$-microglobulin; MA, microalbumin; eGFRcys, estimated glomerular filtration rate level with calculated by Cys $C$. 
A

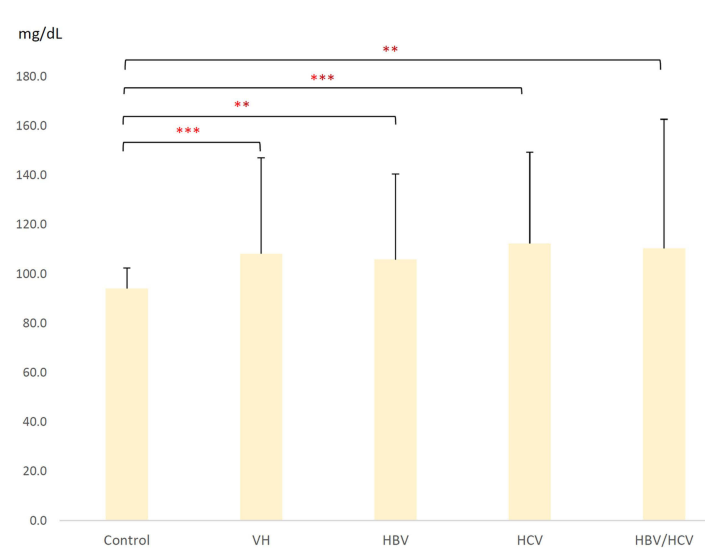

C

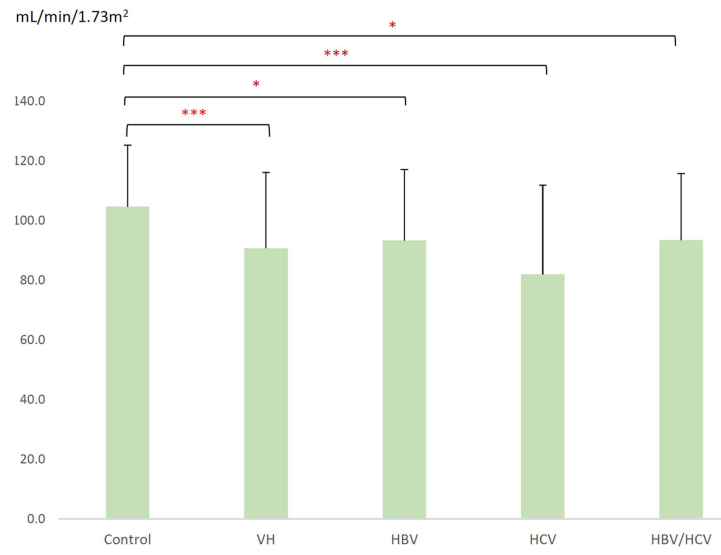

B

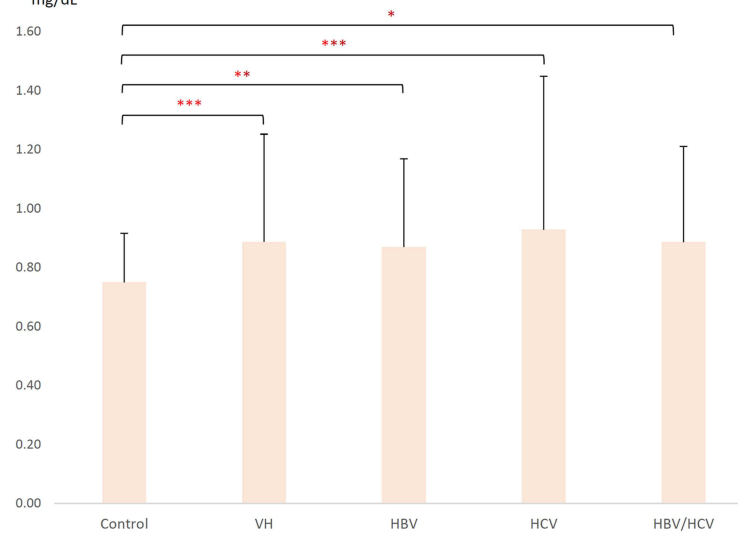

D

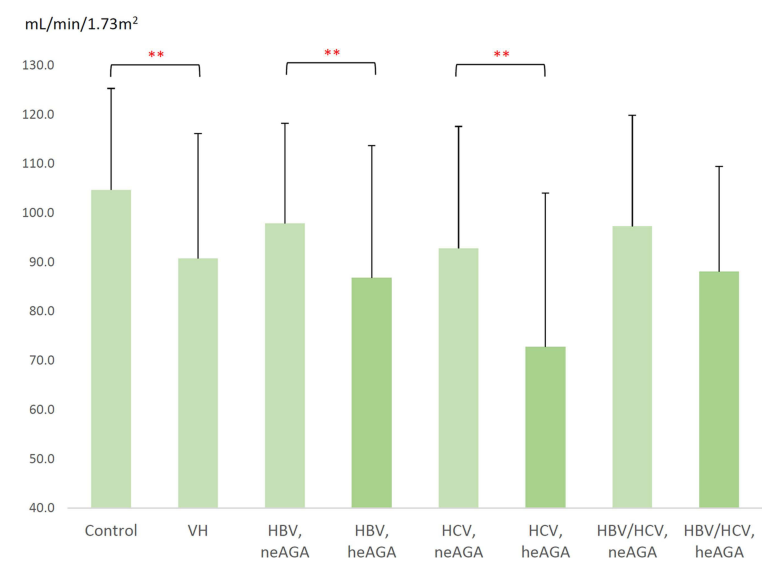

Figure I The glucose values (A) creatinine values (B) and eGFRcys (C) of the HBV, HCV, HBV-HCV subgroups and the control group showed significant differences; (D) average level of eGFRcys was different between the high eAG(GA) and low eAG(GA) groups of patients with viral hepatitis. (*P < $0.05, * * P<0.0 \mathrm{I}$, $* * * \mathrm{P}<0.00 \mathrm{I}$ ).

\section{eGFRcys}

The average level of eGFRcys in the VH group was lower than that in the control group, with significant differences between the HCV subgroup and the control group. The prevalence rates of eGFRcys $<60$ were $10.1 \%$ and $22.4 \%$ in the VH group and HCV subgroup, respectively, and $0.4 \%$ in the control group. (Table 3; Figure 1C)

The chi-square test showed that among 247 (50.3\%) patients with VH, 26 had nephropathy (eGFRcys $<60$ ). The proportion of patients with nephropathy in the VH group was $10.1 \%$ (25 patients), which was higher than the proportion of patients with nephropathy in the non$\mathrm{VH}$ group at $0.4 \%$ (1 patient); the difference was statistically significant $(* * * \mathrm{P}<0.001)$. Among the 26 patients with nephropathy (eGFRcys $<60$ ), the proportion of patients with VH with combined nephropathy and hyperglycemia was $15.7 \%$ (18 patients), while the proportion in the non-VH group was $2.1 \%$
(8 patients); the difference was statistically significant $(* * * \mathrm{P}<0.001)$. The prevalence rates of eGFRcys $<60 \mathrm{~mL} / \mathrm{min} / 1.73 \mathrm{~m}^{2}$ in the HBV, HCV, and HBVHCV subgroups were $7.6 \%$ (11 patients), $22.4 \%$ (13 patients), and $2.3 \%$ (1 patient), respectively. (Table 3).

Glucose, eAG(HbAlc), Cr, Cys C, and $\beta_{2^{-}}$ Microglobulin in the VH Groups with eAG(GA) $\geq 200$ $\mathrm{mg} / \mathrm{dL}$ and $\mathrm{eAG}(\mathrm{GA})<200 \mathrm{mg} / \mathrm{dL}$

The average glucose, eAG(HbAlc), Cr, Cys $\mathrm{C}$, and $\beta_{2^{-}}$ microglobulin levels were higher in the $\mathrm{VH}$ with eAG(GA) $\geq 200 \mathrm{mg} / \mathrm{dL}$ subgroup than in the VH with eAG(GA) $<200 \mathrm{mg} / \mathrm{dL}$ subgroup. More patients with $\mathrm{HBV}, \mathrm{HCV}$, and HBV-HCV with eAG(GA) $\geq 200 \mathrm{mg} / \mathrm{dL}$ were seen compared with those with eAG(GA) $<200 \mathrm{mg} /$ $\mathrm{dL}$, and there were significant differences between the HBV and HCV subgroups and the control group. Marked differences also existed in this regard between the HCV subgroup and control group. (Table 4) 
Table 3 The Compare of Prevalence Rates of eGFRcys $<60 \mathrm{~mL} /$ $\mathrm{Min} / 1.73 \mathrm{~m}^{2}$ in the Control Group, VH Group, and Subgroups (Chi-Square Test)

\begin{tabular}{|c|c|c|c|c|}
\hline \multirow{2}{*}{ Group } & \multicolumn{3}{|c|}{ eGFRcys } & $X^{\mathbf{2}}$ \\
\cline { 2 - 5 } & Mean \pm SD & $\begin{array}{c}\geq 60 ; \\
\text { N (\%) }\end{array}$ & $\begin{array}{c}<60 ; \\
\text { N (\%) }\end{array}$ & P \\
\hline Control & $104.7 \pm 20.6$ & $243(99.6)$ & I (0.4) & $<0.00$ I*** \\
\hline $\begin{array}{c}\text { Viral Hepatitis } \\
\text { HBV }\end{array}$ & $90.7 \pm 25.4$ & $222(89.9)$ & $25(10.1)$ & $<0.00$ I*** \\
HCV & $93.3 \pm 23.8$ & $134(92.4)$ & II (7.6) & \\
HBV-HCV & $93.0 \pm 29.9$ & $45(77.6)$ & I3 (22.4) & \\
\hline HbAIc & $93.5 \pm 22.3$ & $43(97.7)$ & I (2.3) & \\
$\leqq 6.5 \%$ & $97.9 \pm 22.4$ & $368(97.9)$ & $8(2.1)$ & $<0.00$ I*** \\
$>6.5 \%$ & $83.4 \pm 24.1$ & $97(84.3)$ & $18(15.7)$ & \\
\hline
\end{tabular}

Notes: ***P <0.00I; compare each with the control group.

Abbreviations: $\mathrm{HBV}$, hepatitis $B$ virus; $\mathrm{HCV}$, hepatitis $\mathrm{C}$ virus; $\mathrm{HBV}-\mathrm{HCV}$, hepatitis $B+C$ co-infected; HbAlc, glycated hemoglobin.

eGFRcys in the VH with eAG(GA) $\geq 200 \mathrm{mg} / \mathrm{dL}$ and $\mathrm{VH}$ with eAG(GA) $<200 \mathrm{mg} / \mathrm{dL}$ Subgroups

The average eGFRcys level in the VH with eAG(GA) $\geq 200$ $\mathrm{mg} / \mathrm{dL}$ subgroup was significantly lower than that in the $\mathrm{VH}$ with eAG(GA) $<200 \mathrm{mg} / \mathrm{dL}$ subgroup. The average level of eGFRcys in patients with $\mathrm{HBV}, \mathrm{HCV}$, and HBV-HCV with $\mathrm{eAG}(\mathrm{GA}) \geq 200 \mathrm{mg} / \mathrm{dL}$ was lower than that in patients with $\mathrm{eAG}(\mathrm{GA})<200 \mathrm{mg} / \mathrm{dL}$, with significant differences between the HBV and HCV subgroups and the control group. (Table 4; Figure 1D)

\section{Discussion}

VH reduces insulin sensitivity and increases insulin resistance, which is an important factor in the development of
hyperglycemia/DM secondary to chronic liver disease. ${ }^{14,15,16}$ Approximately $80 \%$ of the patients with chronic liver diseases develop glucose intolerance, and $20-30 \%$ eventually develop frank DM. ${ }^{15,17,18}$ In one study, patients with hepatitis B with liver cirrhosis but no symptoms of DM showed impaired glucose tolerance (incidence rate, 20.53\%), and patients with severe liver cirrhosis showed DM (incidence rate, 24.11\%). ${ }^{19}$ Chronic hepatitis $\mathrm{C}$ infection is also associated with $\mathrm{DM} .^{20}$ The prevalence of CKD was reported to be higher in patients infected with HBV than in non-infected individuals. ${ }^{21}$

$\mathrm{HbA1c}$, expressed as a percentage, is an important indicator of blood glucose control in patients with DM. It is widely used as a reference for evaluating the efficacy of medication and drug titration in the treatment of DM. Linear regression analysis of $\mathrm{HbAlc}$ and $\mathrm{eAG}(\mathrm{HbAlc})$ values showed a significant correlation; therefore, $\mathrm{HbAlc}$ levels can be expressed as eAG(HbA1c) for most patients with DM using the formula: eAG(HbAlc) $(\mathrm{mg} / \mathrm{dL})=28.7 \times$ HbA1c - 46.7. ${ }^{9,10}$ GA can more accurately reflect the recent blood sugar control in patients with diabetes-associated endstage renal disease (ESRD) than HbA1c. The correlation equation used to convert $\mathrm{GA}$ into eAG(GA) concentration, ie, $\mathrm{eAG}(\mathrm{GA})(\mathrm{mg} / \mathrm{dL})=4.71 \times \mathrm{GA} \%+73.35$, provides an easy-to-understand blood glucose level for the patients' reference. ${ }^{8}$ Therefore, we used the average glucose, $\mathrm{HbAlc}, \mathrm{eAG}(\mathrm{GA})$, and $\mathrm{eAG}(\mathrm{HbAlc})$ levels to evaluate the glucose status of patients in our study.

Testing for proteinuria is useful in the diagnosis of CKD. The National Kidney Foundation's "K/DOQI Clinical Practice Guidelines for Chronic Kidney Disease:

Table 4 The Average Levels of eGFRcys, eAG(GA), Glucose, eAG(HbAlc), $\mathrm{Cr}$, Cys C, and $\beta_{2}$-Microglobulin in the High eAGe(GA) and Low eAG(GA) Groups of Patients with Viral Hepatitis (ANOVA)

\begin{tabular}{|c|c|c|c|c|c|c|c|}
\hline Group & $\begin{array}{c}\text { eGFRcys } \\
(\mathrm{mL} / \mathrm{min} / \\
\left.1.73 \mathrm{~m}^{2}\right)\end{array}$ & $\begin{array}{l}\text { Glucose } \\
\text { (mg/dL) }\end{array}$ & $\begin{array}{c}\text { eAG(GA) } \\
(\mathrm{mg} / \mathrm{dL})\end{array}$ & $\begin{array}{c}\text { eAG(HbAlc) } \\
(\mathrm{mg} / \mathrm{dL})\end{array}$ & $\mathrm{Cr}(\mathrm{mg} / \mathrm{dL})$ & Cys (mg/L) & $\begin{array}{c}\beta_{2} M G \\
\text { (ug/dL) }\end{array}$ \\
\hline Control & $104.7 \pm 20.6$ & $94.1 \pm 8.4$ & $169.3 \pm 16.1$ & $111.9 \pm 7.0$ & $0.75 \pm 0.17$ & $0.79 \pm 0.14$ & $1.70 \pm 0.50$ \\
\hline $\mathrm{VH}, \mathrm{ne} A \mathrm{G}(\mathrm{GA})$ & $96.8 \pm 21.5$ & $97.0 \pm 18.8$ & $176.5 \pm 14.3$ & $117.7 \pm 18.0$ & $0.83 \pm 0.20$ & $0.86 \pm 0.21$ & $1.88 \pm 0.75$ \\
\hline $\mathrm{VH}, \mathrm{he} A \mathrm{G}(\mathrm{GA})$ & $83.1 \pm 27.8 * * *$ & $|2| .7 \pm 5|| * * *$. & $249.0 \pm 59.0 * * *$ & $|48.4 \pm 47| * * *$. & $0.95 \pm 0.49 *$ & $\mathrm{I} .0 \mathrm{I} \pm 0.4 \mathrm{I}^{* *}$ & $2.58 \pm 1.36 * * *$ \\
\hline HBV, neAG(GA) & $97.9 \pm 20.3$ & $97.3 \pm 19.0$ & $177.0 \pm 14.3$ & $119.4 \pm 17.1$ & $0.83 \pm 0.20$ & $0.85 \pm 0.18$ & $1.82 \pm 0.66$ \\
\hline HBV, heAG(GA) & $86.8 \pm 26.8 * *$ & $117.0 \pm 45.8 * * *$ & $243.9 \pm 60.4^{* * *}$ & $143.6 \pm 48.4 * * *$ & $0.92 \pm 0.39$ & $0.95 \pm 0.32$ & $2.35 \pm 1.16 * *$ \\
\hline $\mathrm{HCV}, \mathrm{ne} A G(\mathrm{GA})$ & $92.8 \pm 24.8$ & $95.0 \pm 12.0$ & $178.5 \pm 16.0$ & $112.8 \pm 19.5$ & $0.79 \pm 0.21$ & $0.92 \pm 0.32$ & $2.12 \pm 1.11$ \\
\hline HCV, heAG(GA) & $72.8 \pm 31.2 * *$ & $127.5 \pm 44.4^{* * *}$ & $265.2 \pm 66.0 * * *$ & $159.4 \pm 46.0$ *** & $1.05 \pm 0.67 * * *$ & $1.18 \pm 0.62 * *$ & $3.11 \pm 1.74 * * *$ \\
\hline HBV-HCV, neAG(GA) & $97.3 \pm 22.6$ & $98.2 \pm 20.2$ & $172.9 \pm 12.5$ & $117.2 \pm 18.9$ & $0.89 \pm 0.16$ & $0.85 \pm 0.17$ & $1.82 \pm 0.55$ \\
\hline HBV-HCV, heAG(GA) & $88.1 \pm 21.4$ & $|28.| \pm 75.9 * * *$ & $240.8 \pm 37.2 * * *$ & $146.0 \pm 43.6 * *$ & $0.89 \pm 0.48$ & $0.94 \pm 0.24$ & $2.43 \pm 1.02$ \\
\hline
\end{tabular}

Notes: $* \mathrm{P}<0.05$, $* * \mathrm{P}<0.01$, $* * * \mathrm{P}<0.001$; Compare each with the control group.

Abbreviations: eAG(GA), estimated average glucose of glycated albumin; neAG(GA), eAG(GA) <200 mg/dL group; heAG(GA), eAG(GA) $\geq 200 \mathrm{mg} / \mathrm{dL}$ group. 
Evaluation, Classification, and Stratification" recommend using eGFR for the assessment of kidney function. ${ }^{22}$ eGFR and urine microalbumin (MA) are also validated as useful tools for the evaluation of renal insufficiency in patients with peripheral arterial disease. ${ }^{23}$ Five-stage eGFR is considered the best indicator of renal function and is widely used in screening patients with CKD. ${ }^{24}$ Usually, the eGFR is based on the patient's serum creatinine $(\mathrm{Cr})$ level. ${ }^{25,26}$ However, eGFRcr obtained using $\mathrm{Cr}$ levels might underestimate the true value of eGFR in patients with an eGFR of $60-80 \mathrm{~mL} / \mathrm{min} / 1.73 \mathrm{~m}^{2,27}$ and $45-60 \mathrm{~mL} / \mathrm{min} / 1.73 \mathrm{~m}^{2}{ }^{28}$ Studies have found that the production of Cys $\mathrm{C}$ is more stable than that of $\mathrm{Cr}^{6,29} \mathrm{Cys} \mathrm{C}$ can be used to estimate eGFRcys as an alternative to eGFRcr as it shows lower variability ${ }^{11}$ and better correlation with the morbidity and mortality rates for different population subsets (including those with CKD). ${ }^{28}$ Hence, the Kidney Disease: Improving Global Outcomes (KDIGO) recommends that regardless of renal damage and/or renal insufficiency, eGFRcys should be measured when the eGFRcr is between 45 and $60 \mathrm{~mL} /$ $\min / 1.73 \mathrm{~m}^{2}$ to reduce the risk of underestimation. ${ }^{6}$ Therefore, we used urine microalbumin, serum $\mathrm{Cr}$, and eGFRcys levels to evaluate the renal function in our study.

In our study, $21.46 \%$ of the patients with VH were at a risk of developing hyperglycemia and $10.12 \%$ were at a risk of developing of CKD with hyperglycemia. Our study revealed a significant association between XMs (such as DM and nephropathy) and chronic viral liver disease. Type $2 \mathrm{DM}$ and CKD have a considerable impact on follow-up medical care, labor, and economy and are associated with poor prognosis and management challenges; hence, disease prevention, screening, and clinical management strategies are urgently required. ${ }^{12,13}$

Our results showed that the average levels of glucose, eAG(GA), and eAG(HbAlc) were significantly higher in the $\mathrm{VH}$ group than in the control group, indicating that $\mathrm{VH}$ is closely associated with the occurrence of type $2 \mathrm{DM}$.

We also found that the average levels of $\mathrm{Cr}$, Cys $\mathrm{C}, \beta_{2}-$ microglobulin, and microalbumin were significantly higher in the VH group, especially in the HCV subgroup than in the control group. The average levels of eGFRcys were significantly higher in the control group than in the three subgroups, indicating that $\mathrm{VH}$ is closely related to the occurrence of $\mathrm{CKD}$.

The Classification and Diagnosis of Diabetes: Standards of Medical Care in Diabetes - 2020 states that in a patient with classic symptoms, the plasma glucose level is adequate to diagnose DM (symptoms of hyperglycemia or hyperglycemic crisis plus a random plasma glucose level of $\geq 200 \mathrm{mg} / \mathrm{dL}$ ).
Table 5 The Risk of Renal Impairment in the Control Group, VH Group, and Combine Hyperglycemia with VH Subgroups (Logistic Regression Models)

\begin{tabular}{|l|c|c|c|c|}
\hline \multirow{2}{*}{ Group } & OR & \multirow{2}{*}{ P } & \multicolumn{2}{|c|}{ 95\% C.I. for OR } \\
\cline { 4 - 5 } & & & Lower & Upper \\
\hline Viral Hepatitis & & & & \\
Control & ref & & & \\
VH & 1.604 & $0.001 * * *$ & 1.20 & 2.14 \\
Hyperglycemia & 1.832 & $0.010^{* *}$ & 1.16 & 2.90 \\
Hyperglycemia with VH & 36.98 & $0.001^{* *}$ & 4.44 & 307.72 \\
\hline
\end{tabular}

Notes: $* * \mathrm{P}<0.01, * * * \mathrm{P}<0.001$; compare each with the control group. Abbreviation: $\mathrm{VH}$, viral hepatitis.

Considering that the GA can accurately reflect the recent blood sugar levels and high blood glucose values after meals (post cibum), it meets the requirements of the American Diabetes Association (ADA) for the diagnosis of DM, and the reference level of eAG(GA) is $200 \mathrm{mg} / \mathrm{dL}$, which we used in our study. ${ }^{30}$

We found that the average levels of glucose, eAG (HbAlc), $\mathrm{Cr}$, Cys $\mathrm{C}$, and $\beta_{2}$-microglobulin were statistically and significantly higher in the $\mathrm{VH}$ patients with eAG(GA) $\geq 200 \mathrm{mg} / \mathrm{dL}$ than in the $\mathrm{VH}$ patients with eAG(GA) $<200 \mathrm{mg} / \mathrm{dL}$. eGFRcys is commonly used in the clinical evaluation of CKD. The average level of eGFRcys was significantly lower in the patients with $\mathrm{VH}$ with eAG(GA) $\geq 200 \mathrm{mg} / \mathrm{dL}$ than in those with eAG(GA) $<200 \mathrm{mg} / \mathrm{dL}$.

An analysis using the logistic regression model found that the risk of renal impairment in the viral hepatitis group was 1.604-fold that of the non-viral hepatitis group. The risk of renal impairment in the hyperglycemia group was 1.832 -fold that of the non-hyperglycemia group. The risk of renal impairment in patients with VH and hyperglycemia was 36.978-fold that of patients with no $\mathrm{VH}$ and hyperglycemia. The results indicate that $\mathrm{VH}$ is closely related to the occurrence of $\mathrm{CKD}$, and hyperglycemia/DM increases the risk of nephropathy in patients with VH. (Table 5).

The possible mechanism could be reduced insulin sensitivity caused by $\mathrm{VH}$, and increased insulin resistance, leading to the development of hyperglycemia/DM, ${ }^{15,16}$ which can lead to renal atherosclerosis and chronic inflammation. ${ }^{31-33}$ However, further research is necessary to confirm the mechanism.

The KDIGO guidelines clearly state that patients with kidney disease who are infected with HCV can be administered anti-viral drugs, and this will have a significant impact on follow-up care and long-term survival. ${ }^{6}$ Studies have also reported that anti-HCV drugs, such as telaprevir (TVR), 
peginterferon (PEG IFN), and ribavirin (RBV), can cause a significant increase in serum $\mathrm{Cr}$ and cys $\mathrm{C}$ and decrease in eGFRcr to $<60 \mathrm{~mL} / \mathrm{min} / 1.73 \mathrm{~m}^{2}$, especially at high doses in case of TVR. ${ }^{34,35}$ All our patients with VH had been routinely followed up for at least 10 years; initially, none of them had hyperglycemia/DM and nephropathy, while some developed these conditions later, especially those $\mathrm{VH}$ and hyperglycemia/ DM. Moreover, none of our patients used anti-viral drugs or other drugs that could affect renal function.

\section{Conclusion}

In conclusion, our study used many parameters to evaluate the glucose level and renal function in patients with $\mathrm{VH}$ and found that hyperglycemia/DM and renal disease (nephropathy) are closely associated with $\mathrm{VH}$, especially in those with $\mathrm{HCV}$ infection. Patients with concurrent VH and hyperglycemia/DM, especially those with HCV infection, are particularly at risk of developing nephropathy. Patients with VH, especially those with $\mathrm{HCV}$ infection, should be closely followed up to evaluate the blood glucose and renal function for the early diagnosis and management of DM and nephropathy.

\section{Abbreviations}

DM, diabetes mellitus; VH, viral hepatitis; HBV, hepatitis $\mathrm{B}$ virus; $\mathrm{HCV}$, hepatitis $\mathrm{C}$ virus; $\mathrm{HBV}-\mathrm{HCV}$, hepatitis $\mathrm{B}+\mathrm{C}$ co-infected; GOT, glutamic oxaloacetic transaminase; HbA1c, glycated hemoglobin; GA, glycated albumin; eAG(GA), estimated average glucose calculated by glycated albumin; eAG(HbA1c), estimated average glucose calculated by HbA1c; CKD, chronic kidney disease; ESRD, end-stage renal disease; $\mathrm{Cr}$, creatinine; Cys $\mathrm{C}$, cystatin C; eGFRcys, estimated glomerular filtration rate calculated by cystatin $\mathrm{C}$; MA, microalbumin; XM, extrahepatic manifestations; HD, hepatogenous diabetes; $\mathrm{DN}$, diabetic nephropathy; WHO, World Health Organization.

\section{Ethics and Informed Consent}

The study was approved by the Tri-Service General Hospital Institutional Review Board (TSGHIRB No.:TC102-01) and conducted in accordance with the principles stated in the Declaration of Helsinki. All participants in the research were given the written informed consent before the health examination to authorize the data analysis. Personal identification data was removed in the Taichung Armed Force General Hospital, so the participants remained anonymous during the whole research process. All or part of the data used in this research were authorized by and received from the
Taichung Armed Force General Hospital. All data accessed complied with relevant data protection and privacy regulations. The detail of the study population and data collection were described and reported in materials and methods.

\section{Acknowledgments}

The authors thank Dr. Yi-Yu Tu from the Department of Endocrine and Metabolism, Dr. Yu-Liang Lai and Dr. WuHsien Kuo from the Gastroenterology Department, Dr. ChaoHung Lai from the Department of Cardiology, Dr.Yu-Ching Li from the Family Medicine Department, Dr. De-Zheng Yue from the Department of Rectal Surgery for their assistance in collecting and consulting the research data.

\section{Author Contributions}

All authors made substantial contributions to conception and design, acquisition of data, or analysis and interpretation of data; took part in drafting the article or revising it critically for important intellectual content; agreed to submit to the current journal; gave final approval of the version to be published; and agree to be accountable for all aspects of the work.

\section{Funding}

This research was entirely funded by the Medical Service Fund of the Taichung Armed Force General Hospital (Research Plan Number: TCAFGH-D-109033).

\section{Disclosure}

The authors report no conflicts of interest in this work.

\section{References}

1. Jefferies M, Rauff B, Rashid H, Lam T, Rafiq S. Update on global epidemiology of viral hepatitis and preventive strategies. World J Clin Cases. 2018;6(13):589-599. doi:10.12998/wjcc.v6.i13.589

2. World Health Organization.. Global hepatitis report 2017; 2017. https://www.who.int/hepatitis/publications/global-hepatitis-report2017/ en/. Accessed May 13, 2021.

3. Iovanescu VF, Streba CT, Ionescu M, et al. Diabetes mellitus and renal involvement in chronic viral liver disease. J Med Life. 2015;8 (4):483-487.

4. Younossi ZM, Birerdinc A, Henry L. Hepatitis C infection: a multi-faceted systemic disease with clinical, patient reported and economic consequences. J Hepatol. 2016;65(1 Suppl):S109-S119. doi:10.1016/j.jhep.2016.07.005

5. Younossi ZM, Henry L, Po J, et al. Systematic review with meta-analysis: extrahepatic manifestations in chronic hepatitis $\mathrm{C}$ virus-infected patients in East Asia. Aliment Pharmacol Ther. 2019;49(6):644-653. doi:10.1111/apt.15131

6. Roth D, Bloom RD, Molnar MZ, et al. KDOQI US commentary on the 2018 KDIGO Clinical Practice Guideline for the Prevention, Diagnosis, Evaluation, and Treatment of Hepatitis C. Am J Kidney Dis. 2020;75(5):665-683. doi:10.1053/j.ajkd.2019.12.016 
7. Garabed Eknoyan M, Norbert Lameire M, Co-Chairs FK, Kai-Uwe Eckardt M, Co-Chair IP. KDIGO 2012 Clinical Practice Guideline for the Evaluation and Management of Chronic Kidney Disease. Guideline. Off J Int Soc Nephrol. 2013;3(1):1-150. doi:10.1038/kisup.2012.73

8. Kim JK, Park JT, Oh HJ, et al. Estimating average glucose levels from glycated albumin in patients with end-stage renal disease. Yonsei Med J. 2012;53(3):578-586. doi:10.3349/ymj.2012.53.3.578

9. Nathan DM, Kuenen J, Borg R, et al. Translating the A1C assay into estimated average glucose values. Diabetes Care. 2008;31 (8):1473-1478. doi:10.2337/dc08-0545

10. Rodriguez-Segade S, Rodriguez J, Paz JM, Camina F. Translating the A1C assay into estimated average glucose values: response to Nathan et al. Diabetes Care. 2009;32(1):e10; author reply e12. doi:10.2337/dc08-1214

11. Stevens LA, Coresh J, Schmid CH, et al. Estimating GFR using serum cystatin $\mathrm{C}$ alone and in combination with serum creatinine: a pooled analysis of 3418 individuals with CKD. Am J Kidney Dis. 2008;51(3):395-406. doi:10.1053/j.ajkd.2007.11.018

12. Avramovic G, Oprea C, Surey J, et al. HepCare Europe-A service innovation project. HepCheck: characteristics of the patient population with active infection as defined by HCV RNA. Int $J$ Infect Dis. 2020;91:246-251. doi:10.1016/j.ijid.2019.11.027

13. Crews DC, Bello AK, Saadi G. 2019 World Kidney Day Editorial burden, access, and disparities in kidney disease. J Bras Nefrol. 2019;41(1):1-9. doi:10.1590/2175-8239-JBN-2018-0224

14. Ammirati AL. Chronic kidney disease. Rev Assoc Med Bras. 2020;66 (Suppl 1):s03-s09. doi:10.1590/1806-9282.66.S1.3

15. Gundling F, Schumm-Draeger PM, Schepp W. Der hepatogene Diabetes - aktueller Stand der Diagnostik und Therapie [Hepatogenous diabetes - diagnostics and treatment]. Z Gastroenterol. 2009;47(5):436-445. doi:10.1055/s-0028-1109200

16. Iliescu L, Mercan-Stanciu A, Toma L, Ioanitescu ES, Severe A. Case of hyperglycemia in a kidney transplant recipient undergoing interferon-free therapy for chronic Hepatitis C. Acta Endocrinol (Buchar). 2018;14(4):533-538. doi:10.4183/aeb.2018.533

17. Chlup R, Ehrmann J. Zvlastnosti diagnostiky a lecby diabetu $\mathrm{u}$ jaternich onemocneni. [Special aspects of diagnosis and therapy of diabetes in liver diseases]. Vnitr Lek. 2001;47(5):320-323.

18. Petrides AS. Der Hepatogene Diabetes: pathophysiologie, therapeutische Besonderheiten und Prognose [Hepatogenic diabetes: pathophysiology, therapeutic options and prognosis]. Z Gastroenterol. 1999;Suppl 1:15-21.

19. Zhang X, Shen W, Shen DM. [A clinical analysis of liver disease patients with abnormal glucose metabolism]. Zhonghua Gan Zang Bing Za Zhi. 2006;14(4):289-292. (Chinese).

20. Mostafa A, Mohamed MK, Saeed M, et al. Hepatitis C infection and clearance: impact on atherosclerosis and cardiometabolic risk factors. Gut. 2010;59(8):1135-1140. doi:10.1136/gut.2009.202317

21. Du Y, Zhang S, Hu M, et al. Association between hepatitis B virus infection and chronic kidney disease: a cross-sectional study from 3 million population aged 20 to 49 years in rural China. Medicine. 2019;98(5):e14262. doi:10.1097/MD.0000000000014262
22. National Kidney Foundation. K/DOQI clinical practice guidelines for chronic kidney disease: evaluation, classification, and stratification. Am J Kidney Dis. 2002;39(2 Suppl 1):S1-266.

23. Endo M, Kumakura H, Kanai H, et al. Prevalence and risk factors for renal artery stenosis and chronic kidney disease in Japanese patients with peripheral arterial disease. Hypertensi Res. 2010;33(9):911-915. doi: $10.1038 / \mathrm{hr} .2010 .93$

24. Hostetter TH, Olson JL, Rennke HG, Venkatachalam MA, Brenner BM. Hyperfiltration in remnant nephrons: a potentially adverse response to renal ablation. Am J Physiol. 1981;241(1):F8593. doi:10.1152/ajprenal.1981.241.1.F85

25. Stevens LA, Coresh J, Greene T, Levey AS. Assessing kidney function-measured and estimated glomerular filtration rate. $N$ Engl $J$ Med. 2006;354(23):2473-2483. doi:10.1056/NEJMra054415

26. Stevens LA, Levey AS. Measured GFR as a confirmatory test for estimated GFR. J Am Soc Nephrol. 2009;20(11):2305-2313. doi:10.1681/ASN.2009020171

27. Murata K, Baumann NA, Saenger AK, Larson TS, Rule AD, Lieske JC. Relative performance of the MDRD and CKD-EPI equations for estimating glomerular filtration rate among patients with varied clinical presentations. Clin J Am Soc Nephrol. 2011;6 (8):1963-1972. doi:10.2215/CJN.02300311

28. Shlipak MG, Matsushita K, Arnlov J, et al. Cystatin C versus creatinine in determining risk based on kidney function. $N$ Engl J Med. 2013;369(10):932-943. doi:10.1056/NEJMoa1214234

29. Stevens LA, Schmid CH, Greene T, et al. Factors other than glomerular filtration rate affect serum cystatin C levels. Kidney Int. 2009;75 (6):652-660. doi:10.1038/ki.2008.638

30. American Diabetes A. 2. Classification and diagnosis of diabetes: standards of medical care in diabetes-2020. Diabetes Care. 2020;43 (Suppl 1):S14-S31. doi:10.2337/dc20-S002

31. Drummond CA, Brewster PS, He W, et al. Cigarette smoking and cardio-renal events in patients with atherosclerotic renal artery stenosis. PLoS One. 2017;12(3):e0173562. doi:10.1371/journal. pone. 0173562

32. Eloueyk AK, Alameddine RY, Osta BA, Awad DM. Correlations between serum inflammatory markers and comorbidities in patients with end-stage renal disease. J Taibah Univ Med Sci. 2019;14 (6):547-552. doi:10.1016/j.jtumed.2019.10.003

33. Becares N, Harmala S, China L, et al. Immune regulatory mediators in plasma from patients with acute decompensation are associated with 3-month mortality. Clin Gastroenterol Hepatol. 2020;18 (5):1207-1215 e6. doi:10.1016/j.cgh.2019.08.036

34. Fukuda K, Imai Y, Hiramatsu N, et al. Renal impairment during the treatment of telaprevir with peginterferon and ribavirin in patients with chronic hepatitis C. Hepatol Res. 2014;44(12):1165-1171. doi:10.1111/hepr.12229

35. Mauss S, Hueppe D, Alshuth U. Renal impairment is frequent in chronic hepatitis $\mathrm{C}$ patients under triple therapy with telaprevir or boceprevir. Hepatology. 2014;59(1):46-48. doi:10.1002/ hep. 26602

\section{Publish your work in this journal}

Diabetes, Metabolic Syndrome and Obesity: Targets and Therapy is an international, peer-reviewed open-access journal committed to the rapid publication of the latest laboratory and clinical findings in the fields of diabetes, metabolic syndrome and obesity research. Original research, review, case reports, hypothesis formation, expert opinion and commentaries are all considered for publication. The manuscript management system is completely online and includes a very quick and fair peer-review system, which is all easy to use. Visit http://www.dovepress.com/testimonials.php to read real quotes from published authors. 